\title{
Analisis Terhadap Tata Kelola Keuangan Desa Citalem Kecamatan Cipongkor Kabupaten Bandung Barat
}

\author{
Bambang Agus Diana ${ }^{1}$
}

\begin{abstract}
ABSTRAK
Salah satu yang menjadi kebutuhan dalam meningkatkan - pengetahuan pemerintahan desa saat ini adalah mengenai pengelolaan keuangan desa, karena tidak sedikit pemerintahan desa masih kurang paham dalam pengelolan tata keuangan yang baik dan benar, apalagi sekarang ini banyak bantuan pemerintah yang diberikan kepada desa, salah satunyanya dana desa, yang semakin besarnya pemberian dana desa yang diberikan pemerintah, sehingga perlu adanya pengelolaan keuangan yang baik dan benar.Dengan disahkannya UU No. 6 Tahun 2014 tentang Desa pada tanggal 15 Januari 2014, pengaturan tentang desa mengalami perubahan secara signifikan. Dari sisi regulasi, desa (atau dengan nama lain telah diatur khusus/tersendiri) tidak lagi menjadi bagian dari UU No. 32 Tahun 2004 tentang Pemerintahan Daerah. Pada hakikatnya UU Desa memiliki visi dan rekayasa yang memberikan kewenangan luas kepada desa di bidang penyelenggaraan pemerintahan desa, pelaksanaan pembangunan desa, pembinaan kemasyarakatan desa, dan pember-dayaan masyarakat desa berdasarkan prakarsa masyarakat, hak asal usul, dan adat istiadat desa. Pada saat penjajagan/penelitian awal ke desa Citalem Kecamatan Cipongkor peneliti lebih cenderung ingin mengamati masalah pengelolaan keuangan desa/ daerah yang terkait dengan pendapatan desa. Tujuan dari penelitian ini adalah untuk memperoleh pengetahuan faktual berkenaan dengan perencanaan anggaran, pelaksanaan, penatausahaan, pelaporan, dan pertanggungjawaban pengelolaan keuangan desa di Desa Citalem Kecamatan Cipongkor Kabupaten Bandung Barat. Keuangan Desa adalah semua hak dan kewajiban Desa dalam rangka penyelenggaraan pemerintahan desa yang dapat dinilai dengan uang termasuk didalamnya segala bentuk kekayaan yang berhubungan dengan hak dan kewajiban desa tersebut. Pendapatan Desa diterima dan disalurkan melalui rekening kas Desa dan penggunaannya ditetapkan dalam APB Desa.
\end{abstract}

Kata kunci : pemerintahan, Pengelolaan dan keuangan desa.

\section{ABSTRACT}

One of the requirements in increasing the current knowledge of village government is regarding village financial management, because not a few village governments still lack understanding in the management of good and right financial arrangements, especially now that much of the government assistance is given to villages, one of which is village funds., the increasing amount of village funding provided by the government, so that there is a need for good and correct financial management. With the enactment of Law No. 6

\footnotetext{
${ }^{1}$ e-mail: bambangad@ecampus.ut.ac.id
} 
of 2014 concerning Villages on January 15, 2014, arrangements regarding villages experienced significant changes. In terms of regulation, villages (or with other names arranged specifically / separately) are no longer part of Law No. 32 of 2004 concerning Regional Government. In essence, the Village Law has a vision and engineering that gives broad authority to the village in the field of village administration, the implementation of village development, village community development, and village community empowerment based on community initiatives, origin rights, and village customs. At the time of the initial assessment / research into the village of Citalem, Cipongkor District researchers were more likely to want to observe the problem of village / regional financial management related to village income. The purpose of this study is to obtain factual knowledge regarding budget planning, implementation, administration, reporting, and accountability of village financial management in Citalem Village, Cipongkor District, West Bandung Regency. Village Finance is all Village rights and obligations in the context of the administration of village governance that can be assessed with money including all forms of wealth related to the rights and obligations of the village. Village income is received and channeled through the village cash account and its use is determined in the Village APB.

Keywords: governance, village management and finance.

\section{A. PENDAHULUAN}

\section{Latar Belakang.}

Desa Citalem Kecamatan Cipongkor adalah wilayah yang berada di Kabupaten Bandung Barat, Provinsi Jawa Barat. Letak desa Citalem berbatasan langsung dengan beberapa desa lainnya, di sebelah Selatan Desa Cijenuk, sebelah Barat yaitu Desa Mekarsari, sebelah utara berbatasan dengan Desa Karang Anyar (Kecamatan Cililin) sebelah timur berbatasan dengan desa Sukamulya, Jumlah penduduk desa Citalem memiliki jumlah penduduk paling banyak diantara desa lainnya dikecamatan Cipongkor. Sekitar 13.689 jiwa, Luas desa Citalem kurang lebih 23 Kilo meter persegi, Fasilitas yang telah ada di desa Citalem adalah lapangan sepak bola desa, pasar desa, Bank BRI, Minimarket (alfamart), kantor Pos, Puskesmas, sarana ibadah/Pondok pesantren, Pendidikan Paud/TK, Sekolah Dasar, Mts, SMA, SMK,dan MA. Sedangkan Mata pencaharian masayarakat desa Citalem pada umumnya adalah bertani, berdagang, Pegawai Swasta/Wiraswasta dan sebagian Pegawai pemerintah/guru.

Dalam menjalankan pemerintahannya desa Citalem memiliki sumber daya manusia (SDM) 12 (dua belas) orang, kebutuhan dalam menjalankan pemerintahan desa perlu didukung oleh banyak hal terutama wawasan dan pengetahuan aparatur pemerintahan desa itu sendiri. Dalam upaya mendukung proses pelaksanaan pemerintahan desa tersebut. UU No. 6 tahun 2014 tentang Desa, memberikan banyak harapan kepada desa untuk meningkatkan kesejahteraan baik aparatur desa maupun masyarakat desa itu sendiri.

\section{Kajian Permasalahan :}

Dengan disahkannya UU No. 6 Tahun 2014 tentang Desa pada tanggal 15 Januari 2014, pengaturan tentang desa mengalami perubahan secara signifikan. Dari sisi regulasi, desa (atau dengan nama lain telah diatur khusus/tersendiri) tidak lagi menjadi bagian dari UU No.32 Tahun 2004 tentang Peme-rintahan Daerah. Desa-desa di Indonesia akan mengalami reposisi dan pendekatan baru dalam pelaksanaan pembangunan dan tata kelola pemerintahannya. Pada hakikatnya UU Desa memiliki visi dan rekayasa yang memberikan kewenangan luas kepada desa di bidang penyelenggaraan pemerintahan desa, 
pelaksanaan pembangunan desa, pembinaan kemasyarakatan desa, dan pemberdayaan masyarakat desa berdasarkan prakarsa masyarakat, hak asal usul, dan adat istiadat desa. Seiring meningkatnya anggaran dana desa yang diberikan pemerintah pusat ke desa-desa, serta meningkatnya pengelolaan keuangan desa lainnya, seperti dari pendapatan asli desa, serta pajak bagi hasil dari kabupaten/kota dan sumbersumber keuangan lainnya yang menjadi penghasilan desa, tuntutan pengelolaan keuangan desa akan menjadi semakin meningkat dan wajib dilakukan.

Amanah Undang-undang Desa dan Permendagri tersebut mensyaratkan kepala desa dan aparatnya harus mengerti tata cara pengelolaan keuangan desa secara transparan, partisipatif dan akuntabel sebagai bentuk dari tertib dan disiplin anggaran desa. Kades sebagai kuasa pengguna anggaran di desa sebagai tuntutan dari Undang-Undang Nomor 6 Tahun 2014 Tentang Desa, harus memiliki kemampuan mengelola keuangan desa. Pengelolaannya harus didasarkan dan sesuai dengan Rencana Pembangunan Jangka Menengah Desa (RPJMD), Rencana Kerja Pemerintah Desa (RKPD) dan APBDesa.

\section{Tujuan Penelitian}

Tujuan dari penelitian ini adalah untuk memperoleh pengetahuan faktual berkenaan dengan perencanaan anggaran, pelaksanaan, penatausahaan, pelaporan, dan pertanggungjawaban pengelolaan keuangan desa di Desa Citalem Kecamatan Cipongkor Kabupaten Bandung Barat.

\section{Kepentingan Penelitian}

Penelitian ini merupakan respon dari bergulirnya dana desa yang diperuntukkan bagi peningkatan pembangunan masyarakat desa, yang mengamanatkan secara khusus kepada Pelaksana Teknis Pengelola Keuangan Desa (PTPKD) untuk dapat mengelola keuangan desa mulai dari perencanaan anggaran, pelaksanaan, penatausahaan, pelaporan, dan pertanggungjawaban pengelolaan keuangan desa dalam upaya memperkuat basis kemandirian desa menuju kesejahteraan masyarakat desa yang sebenarnya di Desa Citalem Kecamatan Cipongkor Kabupaten Bandung Barat.

\section{Metode penelitian}

Pendekatan penelitian yang digunakan untuk mencapai tujuan penelitian adalah pendekatan mixed metode (campuran). Data yang dikumpulkan berupa angka-angka, dan grafik hasil dari analisis serta data berasal dari hasil wawancara, catatan lapangan, dokumen pribadi, catatan memo, dan dokumen resmi lainnya.

\section{B. TINJAUAN PUSTAKA}

\section{Pengelolaan Keuangan Desa}

Penyelenggaraan kewenangan Desa berdasarkan hak asal usul dan kewenangan lokal berskala Desa didanai oleh APBDesa. Penyelenggaraan kewenangan lokal berskala Desa selain didanai oleh APB Desa, juga dapat didanai oleh anggaran pendapatan dan belanja negara dan anggaran pendapatan dan belanja daerah. Penyelenggaraan kewenangan Desa yang ditugaskan oleh Pemerintah didanai oleh anggaran pendapatan dan belanja negara. Dana anggaran pendapatan dan belanja negara dialokasikan pada bagian anggaran kementerian/lembaga dan disalurkan melalui satuan kerja perangkat daerah kabupaten/kota. Penyelenggaraan kewenangan Desa yang ditugaskan oleh pemerintah daerah didanai oleh anggaran pendapatan dan belanja daerah.

Menurut Mulyawan (2013: 9.59), pengertian Keuangan Desa menurut UndangUndang Desa Nomor 6 tahun 2014 tentang Desa adalah semua hak dan kewajiban desa yang dapat dinilai dengan uang serta segala sesuatu berupa uang dan barang yang berhubungan dengan pelaksanaan hak dan kewajiban Desa). Keuangan Desa adalah semua hak dan kewajiban Desa dalam rangka penyelenggaraan pemerintahan desa yang dapat dinilai dengan uang termasuk didalamnya segala bentuk kekayaan yang berhubungan dengan hak dan kewajiban desa tersebut. Pendapatan Desa diterima dan disalurkan melalui rekening kas Desa dan penggunaannya ditetapkan dalam APB Desa. 
Pencairan dana dalam rekening kas Desa ditandatangani oleh kepala Desa dan Bendahara Desa. Pengelolaan keuangan Desa meliputi:

1) perencanaan;

2) pelaksanaan;

3) penatausahaan;

4) pelaporan; dan

5) pertanggungjawaban.

Seperti yang termuat dalam Peraturan Menteri dalam Negeri Republik Indonesia, Nomor 113 Tahun 2014 tentang Pengelolaan Keuangan Desa, Kepala desa merupakan penanggung jawab dari semua bentuk pengelolaan keuangan. Karena desa merupakan pelaksana teknis seluruh pengelolaan keuangan di desa, oleh sebab itu sudah selayaknya pengelolaan keuangan desa, harus di barengi dengan sistem aplikasi Komputer, agar bendahara desa dapat dengan mudah dalam melakukan pengelolaan keuangannya.

Keuangan desa adalah semua hak dan kewajiban desa yang dapat dinilai dengan uang serta segala sesuatu baik berupa uang maupun barang yang berhubungan dengan pelaksanaan hak dan kewajiban desa. (Bab III, bagian 1, pasal 71 point 1 UU Nomor 6 Tahun 2014). Keuangan Desa adalah semua hak dan kewajiban dalam rangka penyelenggaraan pemerintah desa yamg dinilai dengan uang. Termasuk didalamnya segala bentuk kekayaan yang berhubungan dengan hak dan kewajiban desa tersebut. Keuangan desa berasal dari pendapat asli desa, APBD, dan APBN, penyelenggaraan urusan pemerintah desa yang menjadi kewenangan desa didanai oleh APBDes, bantuan pemerintah pusat, dan bantuan pemerintah daerah. (Hanif Nurcholis; 2011: 80)

Menurut Karohadikusumo dalam Sadu Wasistiono (2012:4.3), pada masa lalu desa memiliki dua penghasilan yakni sumber penghasilan yang bersifat tetap dan sumber penghasilan tidak tetap. Namun berdasarkan Undang-undang Nomor 32 Tahun 2004 pasal 212 ayat (3) sumber pendapatan desa terdiri dari:

1) Pendapatan Asli Desa, yakni hasil usaha desa, hasil kekayaan desa, hasil swadaya desa dan partisipasi, hasil gotong royong dan lainlain pendapatan asli desa yang sah.
2) Bagi pajak daerah dan retribusi daerah kabupaten/kota.

3) Bagian dari dana perimbangan keuangan pusat dan daerah yang diterima oleh kabupaten kota.

4) Bantuan dari pemerintah, pemerintah provinsi dan kabupaten.

5) Hibah dan sumbangan dari pihak ketiga.

Alokasi Dana Desa yang dikenal dengan ADD adalah alokasi dana ke desa dengan perhitungan dari Dana Perimbangan yang diterima oleh Kabupaten sebesar 10\% setelah dikurangi dengan Dana Alokasi Khusus (DAK). Dasar hukum pengalokasian Dana Perimbangan ke Desa sesuai dengan amanat dari UndangUndang Nomor 6 Tahun 2014 Pasal 72 ayat (4), jika hal tersebut tidak dilaksanakan maka sanksi tegas dinyatakan dalam Pasal 72 ayat (6), dimana Pemerintah dapat melakukan penundaan dan/atau pemotongan sebesar alokasi Dana Perimbangan setelah dikurangi Dana Alokasi Khusus.

Dana Desa adalah Dana yang bersumber dari Anggaran Pendapatan dan Belanja Negara yang diperuntukan bagi Desa yang ditransfer melalui Anggaran Pendapatan dan Belanja Daerah Kabupaten dan digunakan untuk membiayai penyelenggaraan pemerintahan, pelaksanaan pembangunan, pembinaan kemasyarakatan, dan pemberdayaan masyarakat. Ketentuan yang mengatur Dana Desa adalah Peraturan Pemerintah Nomor 60 Tahun 2014.

Pengalokasian Dana Desa dihitung berdasarkan jumlah desa dan dialokasikan dengan mem-perhatikan jumlah penduduk, angka kemiskinan, luas wilayah, dan tingkat kesulitan geografis. Di dalam Peraturan Pemerintah Nomor 60 Tahun 2014 Pasal 11 ayat (3) mengatur bobot untuk jumlah penduduk sebesar 30\%, luas wilayah $20 \%$ dan angka kemiskinan sebesar $50 \%$ dan dikalikan dengan Indeks Kemahalan Kontruksi Kabupaten. Kemudian Peraturan Pemerintah tersebut direvisi dengan rincian untuk jumlah penduduk bobotnya sebesar $25 \%$, luas wilayah $10 \%$, angka kemiskinan 35\% dan Indeks Kesulitan Geografis sebesar $30 \%$. 
Mengacu pada pustaka yang telah dipaparkan sebelumnya, maka analisis terhadap pengelolaan keuangan Desa Citalem Kecamatan Cipongkor Kabupaten Bandung Barat, adalah sebaga berikut Desa tahap pertama yaitu Perencanaan anggaran yang di ajukan melalui rapat antara Jajaran Kepala Desa dan jajaran BPD dan tokoh Masyarakat, tahap kedua pelaksanaan kegiatan berikutnya setelah rancana anggaran telah dibuat berdasarkan hasil rapat, pemerintah melaksanakan program kerja berdasarkan hasil rapat tersebut dengan menggunakan keuangan sesuai dengan anggaran yang direncanakan, tahap ketiga adalah Penatausahaan, Penata usahaan keuangan dilakukan oleh sekertaris desa/bendahara desa dan staff yang diperbantukan untuk mengadministrasikan seluruh pertanggungjawaban penggunaan keuangan desa, penerimaan dan pengeluaran uang menjadi tanggungjawabnya melalui laporan pertanggungjawaban kekepala desa. Selanjutnya tahap keempat Pelaporan keuangan, dilakukan oleh kepala desa kepada BPD dan tokoh masyarakat setelah program kerja terlaksana dengan baik, pelaporan keuangan ini tentunya harus sesuai dengan buktibukti pengeluaran yang telah direncanakan sebelumnya. Dan tahap kelima adalah pertanggungjawaban dimana pada tahap pertanggungjawaban ini, kepala desa melaporkan seluruh pertanggungjawaban keuangan kepada Bupati melalui camat secara tertulis yang berbentuk laporan program kerja dan laporan keuangan dan laporan kepada tokoh masyarakat/BPD melalui pertemuan yang diselenggarakan oleh pemerintahan desa.

\section{PEMBAHASAN}

\section{Gambaran Umum dan Demografi Desa Citalem}

Desa Citalem adalah sebuah Pemerintahan Desa yang berada di wilayah Kecamatan Cipongkor, Kab. Bandung Barat, Provinsi Jawa Barat. Desa Citalem memiliki luas Wilayah $\pm 590.270 \mathrm{Ha}$, dengan lahan Produktif 369.072 Ha. Yang meliputi Tanah pemukiman, tanah sawah irigasi teknis, tanah sawah irigasi stengah teknis, tanah sawah tadah Hujan tanah tegalan, jalan, sugai, kuburan, dll. Desa Citalem memiliki Jumlah Dusun empat dusun dengan jumlah RT/Rw secara keseluruhan adalah 48 Rukun Tetangga dan 12 Rukun Warga, letak desa Citalem berada disebelah timur kecamatan Cipongkor, jarak dari Desa ke Kecamatan Cipongkor $\pm 8 \mathrm{Km}$ dan ke Kota Kabupaten sekita $47 \mathrm{Km}$. sedangkan batas-batas Desa Citalem adalah : sebelah utara desa Karang Anyar kecamatan Cililin, sebelah timur Desa Sukamulya Kecamatan Cipongkor, sebelah selatan Desa Cijenuk Kecamatan Cipongkor dan sebelah barat Desa Mekarsari Kecamatan Cipongkor. Jumlah penduduk Desa Citalem Kecamatan Cipongkor sebanyak 10.455 Jiwa dengan penduduk usia produktif 3.485 Jiwa sedangkan penduduk yang dikategorikan miskin sekitar 899 jiwa.

Menurut hasil wawancara dengan Kepala desa Citalem, Mata pencaharian sebagian penduduk adalah petani, sedangkan untuk hasil pertanian yang menonjol adalah padi dan Jagung. Penduduk desa Citalem selain terdiri dari penduduk asli dan penduduk pendatang/pindahan dari desa lain, bahkan ada juga dari suku jawa yang berdagang dan bahkan menjadi penduduk desa. Untuk persentase perbandingan antara penduduk produktif, penduduk tidak/belum Produktif dan miskin dapat dilihat dari presentasi pada grafik berikut :

Sumber Gbr 2. Hasil Olahan tentang data keadaan

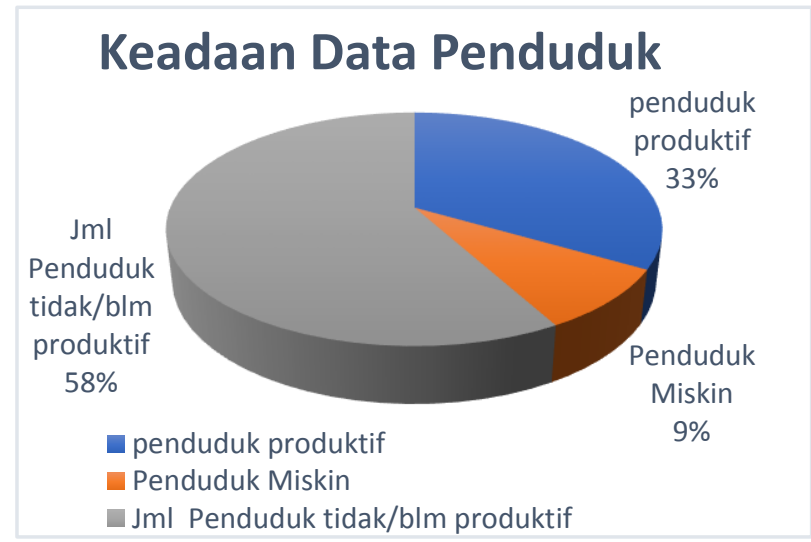

Penduduk Desa Citalem Kec. Cipongkor Kab.Bandung Barat

Penyelenggaraan pemerintahan tidak terlepas dengan masalah pengelolaan keuangan 
sebagai sumber kelancaran pelaksanaan penyelenggaraan pemerintahan, baik dipusat maupun daerah termasuk pemerintah desa, dengan pengelolaan keuangan yang baik dan bersih akan berdampak pula kepada kelancaran dalam pertanggungjawaban pengelolaan keuangan yang sehat dan terhindar dari Korupsi. Pentingnya perencanaan kerja dalam menyelenggarakan jalannya pemerintahan perlu adanya upaya semua pihak penyelenggara pemerintah baik tingkat pusat maupun tingkat daerah bahkan sampai ke tingkat pemerintahan desa. Pemerintahan desa Citalem merupakan salah satu desa yang telah berusaha melaksanakan Rencana Kerja Pemerintahan (RKP) Desa, hal ini dapat dibuktikan dengan adanya Peraturan Desa Nomor 2 Tahun 2016 Tentang Rencana Kerja Pemerintahan Desa Citalem Tahun 2016. RKP desa ini menjadi acuan penyusunan dokumen anggaran pendapatan dan Belanja Desa (APBDesa) sebagai hasil output dari musrembang tahunan desa. Pendapatan desa meliputi semua penerimaan yang merupakan Hak desa dalam satu tahun anggaran yang akan menentukan pendapatan desa, dimana merupakan perkiraan yang terukur secara rasional yang dicapai untuk setiap pendapatan. Sumber-sumber pendapatan desa meliputi Pendapatan Asli Desa (PAD), dana perimbangan, lain-lain pendapatan desa dan pinjaman desa.

Selain itu hasil wawancara lainnya dengan Kepala desa Citalem mengatakan bahwa selama empat tahun terakhir pendapatan desa Citalem mengalami fluktuatif dimana pendapatan desa naik turun pada tiap tahunnya. Defisit APBDesa sebagaimana dialami banyak desa terjadi juga pada Pemerintahan Desa Citalem. Menurut kepala desa pemerintahan desa Citalem merumuskan beberapa kebijakan umum yang akan menjadi panduan pemerintahan desa Citalem dalam menjalankan programprogram Pembangunan pemerintahannya untuk itu selalu berusaha untuk menyeimbangkan program-program yang dibuat dengan keuangan yang ada mana-mana lebih dulu diutamakan.

Kebijakan tersebut antara lain: anggaran diupayakan dapat memenuhi prinsip keseimbangan finansial yaitu antara pendapatan dengan belanja terdapat keseimbangan, pemerintahan Desa Citalem di dominasi oleh dana bagian perolehan Pajak dan Retribusi dari Kabupaten sebesar $65.2 \%-68 \%$ sedangkan pendapatan asli sebesar 32\%-34.8\%, dan pada Tahun 2009 mulai mendapat bantuan dari Kabupaten untuk penghasilan tetap Kades dan staf, serta adanya bantuan Provinsi. Pendapatan hasil pajak/dana perimbangan kabupaten sebesar 26.6\% disusul Pendapatan Asli Desa sebesar $25.45 \%$ dan bantuan Provinsi sebesar $2.35 \%$, pada tahun 2010 terjadi peningkatan tambahan penghasilan kasdes dan perangkat sebesar 48.56\%, ADD 26.4\%, pendapatan Asli Desa $21.7 \%$ dan Bantuan dari provinsi $32.8 \%$.

Sumber: Peraturan Desa Nomor 03 Tahun 2016 Tentang Anggaran Pendapatan dan Belanja (APBDesa) Citalem Tahun Anggaran 2016.

Tabel 1 . Rincian Pendapatan Desa Citalem Kecamatan Cipongkor Kab. Bandung Barat

\begin{tabular}{|c|l|r|}
\hline NO & \multicolumn{1}{|c|}{ Jenis Pendapatan } & \multicolumn{2}{|c|}{ Jumlah Anggaran } \\
\hline 1 & Pendapatan Asli Desa & Rp. $120.000 .000,-$ \\
\hline 2 & Pendapatan transfer & Rp. 1.645.610.285,- \\
\hline 3 & Bantuan Keuangan & RP. $219.600 .000,-$ \\
\hline 4 & Bantuan Lain-lain & Rp 0,- \\
\hline & Jumlah & Rp. 1.985.210.285,- \\
\hline
\end{tabular}

Sumber : Kantor Desa Citalem Kecamatan Cipongkor Kabupaten Bandung Barat

Dan jika dilihat dari grafik persentase pendapatan desa Citalem dapat dilihat sebagai berikut :

\section{Pendapatan Desa}

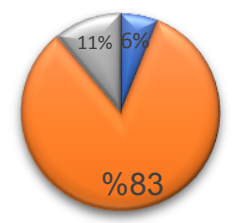

$\square$ PAD $\square$ Pendapatan Transfer $\square$ Bantuan Keuangan

Sumber Gbr 3: Hasil Olahan dari data penelitian 
Terkait dengan masalah pengelolaan keuangan desa Citalem Kecamatan Cipongkor, Kab. Bandung Barat dalam melaksanakan pengelolaan keuangan desa, melalui perencanaan anggaran adalah sebagai berikut :

\section{a. Perencanaan Anggaran}

Bahwa Pemerintahan Desa Citalem dalam melaksanakan Rencana Pembangunan Jangka Menengah Desa (RPJM Desa) selalu mengacu kepada dokumen-dokumen Rencana Pembangunan Jangka Menengah Desa (RPJM Desa) yang di buat bersama-sama dengan masyarakat dan Badan Permusyawaran Desa (BPD) Citalem, dan itu adalah sebagai acuan dalam pelaksanaan rencana pembangunan desa.

\section{b. Pelaksanaan APBD Desa}

Bahwa dana penerimaan dan pengeluaran keuangan desa Citalem kecamatan Cipongkor selalu tersimpan di kas desa atau rekening desa hal tersebut menurut wawancara adalah sudah aturan yang ditetapkan oleh pemerintah untuk menjaga hal- hal yang tidak diinginkan, karena dengan demikian baik pengeluaran maupun dana yang masuk hanya dapat mengalir dari satu kas rekening desa, agar tidak terjadi penyimpangan keuangan desa. Dengan adanya satu kas rekening desa akan mempermudah dalam memonitoring baik dana yang masuk maupun keluar.

\section{c. Penatausahaan Keuangan Desa}

Pada dasarnya setiap pemerintahan baik pusat maupun daerah diwajibkan melakukan penataan usahaan dan pengelolaan keuangan, agar setiap uang yang masuk dan keluar tertulis dan terdokumentasikan dengan baik sehingga mempermudah dalam mempertanggungjawabkan dana yang dipergunakan, karena dana pelaksanaan pemerintahan bersumber dari Anggaran Negara dan daerah oleh karena itu wajib adanya setiap pemerintah mempertanggungjawabkannya melalui pengelolaan keuangan yang baik.

\section{d. Laporan Bendahara Desa}

Sekretaris desa, bendahara dan staf desa Citalem, bahwa bendahara desa selalu melaksanakan tutup buku catatan pengeluaran pemerintahan desa, salah satunya adalah catatan buku umum yang dilaporkan kepada kepala Desa pada setiap awal bulan (laporan bulan sebelumnya).

\section{e. Pelaporan Pertanggungjawaban Keuangan Desa}

Ketua BPD, sekertaris, bendahara dan staf pemerintahan desa Citalem Kec. Cipongkor, bahwa kepala desa dalam rapat semesteran selalu melaporkan hasil kegiatan dan pertanggunjawaban keuangan kepada BPD dan peserta rapat yang dihadiri juga tokoh masyarakat, hal tersebut menurutnya agar masyarakat mengetahui terkait dengan pengelolaan dan program Pembangunan Desa yang telah dilaksanakan dan yang sedang berjalan

Secara umum pelaksanaan pengelolaan keuangan desa Citalem Kecamatan Cipongkor, Kabupaten Bandung barat telah dilaksanakan secara teratur seperti telah memiliki kode rekening /kode anggaran penggunaan dana, adanya pembukuan, dokumentasi laporan pertanggungjawaban, dan pelaporan pertanggungjawaban dilakukan sesuai dengan mekanisme yang ada, namun masih belum sepenuhnya pengelolaan tersebut dapat dijalankan atau terdokumentasikan dengan baik. Hal ini terlihat seperti pada pencatatan pembukuan pada buku Bank, Buku Kas Pembantu pajak, belum dapat dilaksanakan sepenuhnya karena terkait dengan kemampuan sumber daya manusianya dengan latar belakang pendidikan yang tidak sesuai dengan bidangnya.

Oleh karena itu, ke depan perlu adanya perbaikan yang harus dilakukan, seperti pendidikan dan latihan mengenai pengelolaan keuangan, sehingga pengelolaan keuangan Pemerintahan desa Citalem dapat sepenuhnya terkelola dengan baik terutama dalam dokumentasi dan pembuatan pelaporan keuangan, selain itu perlu adanya fasilitas yang dapat memberikan informasi yang baik terhadap masyarakat, melalui pemanfaatan media sosial. 


\section{PENUTUP}

\section{Kesimpulan}

Berdasarkan hasil analisis dengan aparatur Pemerintahan Desa Citalem Kecamatan Cipongkor Kabupaten Bandung barat, bahwa pengelolaan keuangan pada pemerintahan desa Citalem Kecamatan Cipongkor dapat disimpulkan sebagai berikut :

a. Pengelolaan keuangan Pemerintahan desa Citalem, Kecamatan Cipongkor Kab. Bandung Barat telah melaksanakan pengelolaan keuangan dengan tertib, seperti telah melakukan pencatatan pengelolaan keuangan, baik pemasukan maupun pengeluaran keuangan, pencatatan tersebut selain dalam buku juga dalam Komputer.

b. Pertanggungjawaban keuangan berupa laporan laporan keuangan baik dari bendahara ke kepala desa dan kepala desa Ke Bupati melalui camat, serta kepala desa ke masyarakat melalui rapat dengan Badan Permusyawaran Desa (BPD) telah berjalan sebagaimana mestinya, walaupun terkadang mengalami keterlambatan karena masalah teknis, namun pada dasarnya telah dapat berjalan dan dapat dilaksankan dengan baik namun terkadang melebihi batas waktu yang ditetapkan.

c. Dalam pengelolaan keuangannya pemerintahan desa Citalem juga telah menggunakan kode rekening dalam pengelolaan keuangan, sehingga setiap penggunaan anggaran yang digunakan selalu merujuk kepada jenis atau kode anggaran (sesuai kode rekening).

d. Untuk penggunaan sarana informasi agar masyarakat bisa mengetahui program perencanaan kerja pemerintahan desa, termasuk masalah pelaporan keuangan, pemerintahan desa Citalem belum sepenuhnya dapat memberikan informasi melalui media yang ada karena terkait masalah sarana dan fasilitas, namun bentuk penyampaian informasi terhadap masyarakat baru sebatas melalui rapat, dan papan pengumuman di kantor pemerintahan desa. Dari pantauan penelitian yang kami temukan, papan informasi penggunaan dana dalam program pelaksanaan proyek belum dilaksanakan dengan baik, sebagai contoh dalam renovasi Pembangunan Kantor Desa tidak terpasang papan informasi dengan jelas pada pelaksanaan pembangunan dan biaya yang digunakan sehingga tidak terlihat oleh masyarakat.

\section{DAFTAR PUSTAKA}

HAW. Widjaja. 2008. Otonomi Desa merupakan otonomi yang asli bulat dan utuh. Jakarta: Rajawali Pers.

Nurcholis, Hanif. 2011. Pertumbuhan dan Penyelenggaraan Pemerintah Desa. Jakarta: Erlangga.

Mulyawan, Rahman \& Enceng, 2013. Adminsitrasi Keuangan. Jakarta: Universitas Terbuka.

Sadu \& Wasistono \& M.Irwan T. 2012. Administrasi Pemerintahan Desa. Jakarta: Universitas Terbuka.

Soleh, Chabib dan R.Heru. 2014. Pengelolaan Keuangan Desa. Bandung: Fokus Media. Cet. ke-1

\section{Dokumen}

Buku Laporan kajian sistem Pengelolaan Keuangan Desa, 2015 : Deputi Bidang Pencegahan, KPK.

Buku Petunjuk Pelaksanaan Bimbi ngan \& Konsultasi Pengelolaan Keuangan Desa, 2015: BPKP.

Pedoman Aistensi Akuntansi Keuangan Desa, 2015, IAI-KASP.

Undang-Undang Nomor. 6 Th. 2014 Tentang Desa. 
Peraturan Pemerintah (PP) RI No.43 Th. 2014

Tentang Peraturan Pelaksanaan UndangUndang Nomor. 6 Th. 2014 Tentang

Desa.

Peraturan Menteri dalam Negeri Republik

Indonesia, Nomor 113 Tahun 2014

tentang Pengelolaan Keuangan Desa

Peraturan Desa Nomor 02 Tahun 2016 Tentang

Rencana Kerja Pemerintahan (RKP) Desa

Citalem Tahun Anggaran 2016

Peraturan Desa Nomor 03 Tahun 2016 Tentang

Anggaran Pendapatan dan Belanja

(APBDes) Desa Citalem Tahun Anggaran

2016 